\title{
Distinctive Electrophoretic Patterns of Esterases from Levinea malonatica, Levinea amalonatica and Citrobacter
}

\author{
By Рн. GOULLET \\ Laboratoire de Microbiologie, Faculté de Médecine Xavier-Bichat, \\ Université Paris VII, Institut Biomédical des Cordeliers, \\ 2 I, rue de l'École de Médecine, 75270 Paris Cedex 06, France \\ AND C. RICHARD \\ Service des Entérobactéries, Institut Pasteur, 28, rue du Docteur Roux, \\ 75724 Paris Cedex 15, France
}

(Received 22 June 1976; revised 6 August 1976)

\section{SUMMARY}

Esterases of 42 strains of Levinea malonatica, Levinea amalonatica and Citrobacter were analysed by horizontal slab electrophoresis in polyacrylamide-agarose gel using several synthetic substrates. On the basis of esterase zymograms a distinctive pattern was established for each of the three species. Levinea malonatica was characterized by two major bands: one hydrolysing acetate esters but not butyrate esters; and the other hydrolysing $\alpha$-naphthyl acetate and reacting weakly with $\alpha$-naphthyl butyrate and $\beta$-naphthyl acetate. Levinea amalonatica showed one prominent band that hydrolysed $\alpha$-naphthyl esters and reacted weakly with $\beta$-naphthyl esters. Citrobacter strains showed one major band that hydrolysed $\alpha$-naphthyl esters and appeared slightly more active towards $\beta$-naphthyl esters than that of $L$. amalonatica. Considerable variations in electrophoretic mobility were observed among Citrobacter strains. Levinea amalonatica was less variable. In addition, one minor anodal band reacting with $\beta$-naphthyl acetate was observed in both L. malonatica and Citrobacter.

The relative molecular sizes of the major esterase bands were determined by disc electrophoresis with gels of different acrylamide concentrations. The molecular size of the major band of Citrobacter appeared to be smaller than that of the corresponding esterase band of L. amalonatica.

\section{INTRODUCTION}

Levinea is a new genus recently described by Young et al. (197I) and is composed of two species, L. malonatica and L. amalonatica. These differ from each other and from Citrobacter in biochemical characteristics (Young et al., I97I ; Richard, Brisou \& Lioult, I972) as well as polynucleotide sequences (Crosa et al., 1974). The aim of this work was to establish whether these three species may be differentiated by their esterase (EC. 3. I I . ) patterns, as reported for other enterobacteria (Goullet, 1973, 1975).

\section{METHODS}

The bacteria used are listed in Table $\mathbf{I}$.

Biochemical and physiological tests were as previously described (Richard et al., I972). Growth conditions, preparation of extracts, heat denaturation, inhibition by di-iso- 
Table I. Levinea and Citrobacter strains examined

\begin{tabular}{|c|c|c|c|c|c|c|c|c|}
\hline \multirow[b]{2}{*}{ Code } & \multirow{2}{*}{$\begin{array}{c}\text { Strain } \\
\text { designation }\end{array}$} & \multirow[b]{2}{*}{ Origin,* place and date } & \multicolumn{5}{|c|}{ Carbohydrate fermentation $\dagger$} & \multirow[b]{2}{*}{ Biotype $\ddagger$} \\
\hline & & & Sorbose & Dulcitol & Sucrose & Raffinose & Melibiose & \\
\hline & Levinea malonatica & & & & & & & \\
\hline I & M212.73 & Urine, Brussels, 1973 & - & - & - & - & - & a \\
\hline 2 & M227.73 & Urine, Strasbourg, 1973 & - & - & - & - & - & a \\
\hline 3 & M236.73 & Urine, Paris, 1973 & - & - & - & - & - & a \\
\hline 4 & M303.74 & Blood, Saint-Denis, 1974 & - & - & - & - & - & a \\
\hline 5 & M94.72 & Urine, Paris, 1972 & - & + & - & - & - & c \\
\hline 6 & M33.73 & Trachea, Toulon, I973 & - & + & - & - & - & c \\
\hline 7 & M208.73 & Urine, Strasbourg, I973 & - & + & + & - & - & d \\
\hline 8 & M220.73 & Blood, St Etienne, I973 & - & + & + & - & - & d \\
\hline 9 & M229.73 & Faeces, Strasbourg, 1973 & - & + & + & - & - & d \\
\hline ro & M310.74 & Environment, Strasbourg, 1974 & - & + & + & - & - & $\mathrm{d}$ \\
\hline II & M327.74 & Urine, Paris, I974 & - & + & + & - & - & d \\
\hline 12 & M235.73 & Trachea, Paris, I973 & $(+)$ & - & + & - & - & e \\
\hline 13 & M3I2.74 & Pus, Paris, 1974 & $(+)$ & - & + & - & - & e \\
\hline 14 & M328.74 & Urine, Paris, 1974 & - & - & + & - & - & e \\
\hline & Levinea amalonatica & & & & & & & \\
\hline $\begin{array}{l}15 \\
16\end{array}$ & A195.64 & Faeces, Levallois-Perret, 1964 & + & - & - & - & - & b \\
\hline $\begin{array}{l}16 \\
17\end{array}$ & Al96.65 & & + & - & - & - & - & b \\
\hline $\begin{array}{l}17 \\
18\end{array}$ & A30.70 & $\begin{array}{l}\text { Urine, Paris, } 1970 \\
\text { Faeces, Cairo, 197I }\end{array}$ & + & - & - & - & - & b \\
\hline & A6r.7r & Faeces, Cairo, 197I & + & - & - & - & - & b \\
\hline $\begin{array}{l}19 \\
20\end{array}$ & A95.72 & Faeces, Lyon, 1972 & + & - & - & - & - & b \\
\hline 20 & A188.73 & Faeces, South Korea, 1973 & + & - & - & - & - & b \\
\hline $2 \mathrm{I}$ & A211.73 & Faeces, Brussels, 1973 & + & - & - & - & - & b \\
\hline 22 & A226.73 & Faeces, Strasbourg, 1973 & + & - & - & - & - & $\mathrm{b}$ \\
\hline 23 & A231.73 & Faeces, Prague, 1973 & + & - & - & - & - & b \\
\hline 24 & A273.74 & Faeces, Strasbourg, 1974 & + & - & - & - & - & b \\
\hline 25 & A279.74 & Faeces, Madrid, 1974 & + & - & - & - & - & $\mathrm{b}$ \\
\hline 26 & A305.74 & Faeces, St Etienne, I974 & + & - & - & - & - & b \\
\hline 27 & A317.74 & Faeces, Upper Volta, I974 & + & - & - & - & - & b \\
\hline 28 & A325.74 & Faeces, Annecy, I974 & + & - & - & - & - & b \\
\hline 29 & $\begin{array}{l}\text { Citrobacter sp. } \\
\text { FM.14 }\end{array}$ & Urine. Paris, 1970 & $(+)$ & - & - & - & - & \\
\hline 30 & $47.7 \mathrm{I}$ & Faeces, Rouen, I971 & + & - & - & - & - & \\
\hline $3 \mathbf{I}$ & 7.72 & Urine, St Germain-en-Laye, 1972 & $72+$ & + & + & + & + & \\
\hline 32 & 12.72 & Faeces, Baghdad, 1972 & + & - & + & - & + & \\
\hline 33 & 14.72 & Faeces, Baghdad, 1972 & + & + & - & - & + & \\
\hline 34 & 66.72 & Faeces, Perigueux, 1972 & + & + & - & - & + & \\
\hline 35 & 13.74 & Faeces, Colmar, 1974 & + & + & - & - & - & \\
\hline 36 & 25.74 & Throat, Tangier, I974 & + & - & + & + & + & \\
\hline 37 & 26.74 & Faeces, Orly, I974 & $(+)$ & + & - & - & + & \\
\hline 38 & 30.74 & Faeces, Montmorency, 1974 & + & + & + & - & - & \\
\hline 39 & 75.74 & Faeces, Forminy, 1974 & + & + & - & - & - & \\
\hline 40 & 76.74 & Faeces, St Cyr, I974 & + & + & + & $(+)$ & + & \\
\hline $4 \mathrm{r}$ & 77.74 & Faeces, Provins, 1974 & + & + & + & + & + & \\
\hline 42 & 81.74 & Faeces, Le Mans, I974 & - & + & - & - & + & \\
\hline
\end{tabular}

fluoropropyl phosphate (DFP), protein estimation, acrylamide-agarose gel electrophoresis and esterase staining were as described previously (Goullet, I973, 1975), with the following modifications. Bacteria were grown in L broth (Lennox, 1955) without glucose and harvested during the exponential phase. They were washed twice in $0.06 \mathrm{M}$-Tris/glycine buffer, $\mathrm{pH} \mathrm{8.7,} \mathrm{before} \mathrm{ultrasonic} \mathrm{disruption.} \mathrm{Esterase} \mathrm{bands} \mathrm{of} \mathrm{E.} \mathrm{coli} \mathrm{KI2} \mathrm{(Goullet,} \mathrm{1973)} \mathrm{were}$ used as a parallel electrophoretic control. DFP (Calbiochem) was used at $10^{-6}$ to $\mathrm{IO}^{-3} \mathrm{M}$.

Disc electrophoresis. The buffer and gel solutions were as described by Davis (1964). Gel columns were formed in glass tubes $(80 \times 4 \mathrm{~mm})$. For small pore gel, the bisacrylamide/ acrylamide weight ratio was kept constant at $\mathrm{I}: 30$ and the acrylamide was varied from 5 to $12 \%(\mathrm{w} / \mathrm{v})$. The same small pore gel concentration was used for each run. The tracking dye was bromophenol blue. Electrophoresis was at room temperature in a Canalco model I 200 apparatus using $2 \mathrm{~mA}$ per tube until the dye front had migrated into the small pore gel; thereafter $5 \mathrm{~mA}$ per tube was maintained until the dye front had migrated to $40 \mathrm{~mm}$. 


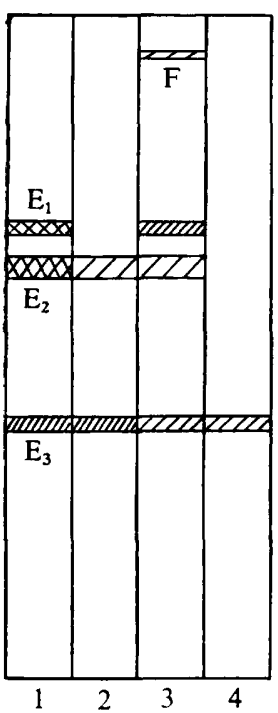

(a)

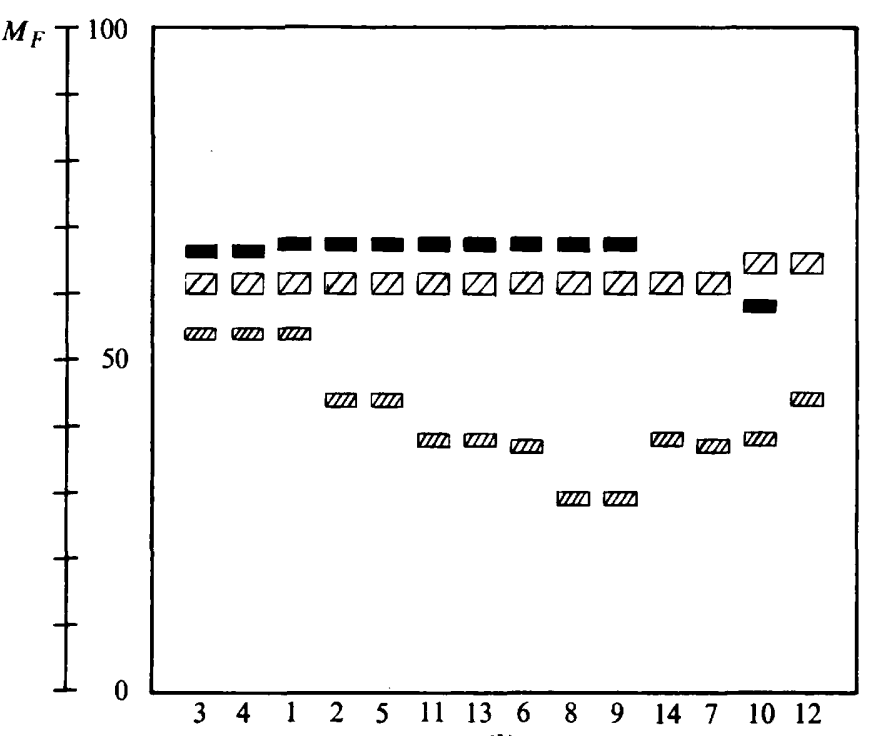

(b)

Fig. I. Levinea malonatica. (a) Schematic representation of mobility and activity of esterase bands (strain I I). Horizontal slab acrylamide-agarose gel electrophoresis was performed using $7 \%(w / v)$ acrylamide and discontinuous Tris/glycine buffer, pH 8.7 (Uriel, 1966). Esterase activity was revealed by the method of Uriel (I96I). Substrates used were: I, $\alpha$-naphthyl acetate; $2, \alpha$-naphthyl butyrate; $3, \beta$-naphthyl acetate; $4, \beta$-naphthyl butyrate. Relative intensity of staining: $\otimes>$ $\square \mathbb{Z}>\square]>\square D$. (b) Esterase patterns of the 14 strains arranged in order of increasing mobility of $\mathrm{E}_{2}$ esterase bands. $\square, \mathrm{E}_{1}$ band; $\square \square, \mathrm{E}_{2}$ band; $Z 7, \mathrm{E}_{3}$ band. The $M_{F}$ values were only used comparatively.

The esterases were stained by $\alpha$-naphthyl acetate (Sigma) using naphthanil diazo blue B (Dajac Laboratories, Philadelphia, Pennsylvania, U.S.A.) as dye coupler.

Electrophoretic mobility. The $M_{F}$ value, i.e. the distance moved by the esterase band as a percentage of the distance moved by the dye front, was the average obtained from four to six runs.

\section{RESULTS}

Reproducible esterase patterns of $L$. malonatica, $L$. amalonatica and Citrobacter were obtained with the four synthetic substrates. All $M_{F}$ values were approximate because of variations between different runs. However, electrophoretic relationships could be established between the strains by numerous replicate assays comparing esterase bands in adjacent positions on the same gel.

\section{Levinea malonatica}

In general, two major bands were observed (Fig. I $a$ ). The faster moving esterase band $\left(\mathrm{E}_{1}\right)$ hydrolysed $\alpha$ - and $\beta$-naphthyl acetates but not butyrate esters; it was inhibited by I0 ${ }^{-5} \mathrm{M}$-DFP. The second band $\left(\mathrm{E}_{2}\right)$ hydrolysed $\alpha$-naphthyl acetate and reacted weakly with $\alpha$-naphthyl butyrate and $\beta$-naphthyl acetate; it was inhibited by $5 \times 10^{-5} \mathrm{M}$-DFP. These two esterase bands were inactivated by 10 min treatment at $60^{\circ} \mathrm{C}$. They were accompanied by a slower moving band $\left(\mathrm{E}_{3}\right)$ which was less deeply stained by $\alpha$-naphthyl acetate than the major bands, but reacted with the other three substrates. One minor fast migrating band $(\mathrm{F}), M_{F} \approx 94$, was detected by $\beta$-naphthyl acetate. Bands $\mathrm{E}_{2}$ and $\mathrm{E}_{3}$ were seen in all I4 strains (Fig. $\mathrm{I} b$ ). The $\mathrm{E}_{3}$ band showed several types of electrophoretic mobility. In 


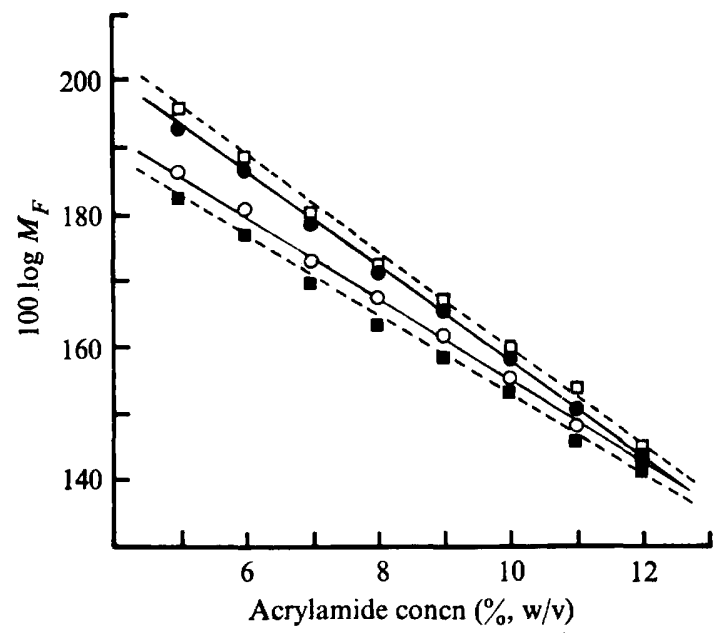

Fig. 2. Plot of logarithm esterase mobility versus gel concentration. L. malonatica (strain II); Iotg $\alpha=7 \cdot 3$. $\bigcirc \longrightarrow \bigcirc$, Esterase band $\mathrm{E}_{2}$ of $L$. malonatica (strain II); $\operatorname{Iotg} \alpha=6 \cdot \mathrm{I}$. $\square---\square$, Major esterase band of L. amalonatica (strain 27); $\operatorname{Iotg} \alpha=7 \cdot 4$. Major esterase band of Citrobacter sp. (strain 40); $\operatorname{lotg} \alpha=6 \cdot 0$.

strain 10 , the $\mathrm{E}_{1}$ band migrated more slowly than the $\mathrm{E}_{2}$ band; in strains 7,12 and 14 it was not detected. No biotype pattern was noted.

According to Hedrick \& Smith (I968), the negative slope (Iotg $\alpha$ ) of the straight line obtained by plotting $100 \log M_{F}$ against gel concentration is directly related to molecular size. The effect of varying the acrylamide concentration on the relative mobility of bands $E_{1}$ and $E_{2}$ (strain II) indicated that the molecular size of esterase band $E_{1}$ was greater than that of esterase band $E_{2}$ (Fig. 2).

\section{Levinea amalonatica}

One prominent esterase band hydrolysed $\alpha$-naphthyl esters and reacted weakly with $\beta$-naphthyl esters (Fig. 3a). It was inactivated by Io min treatment at $60{ }^{\circ} \mathrm{C}$ and strongly inhibited by $10^{-6} \mathrm{M}$-DFP (Fig. 5). In addition, one minor band was often detected by $\alpha$-naphthyl acetate. The major band was observed in all 14 strains (Fig. $3 b$ ). Despite their different geographical origins, strains $18,20,21,23,25$ and 27 appeared identical in terms of major band mobility.

The influence of acrylamide concentration on the relative mobility of the major band of strain 27 is shown in Fig. 2.

\section{Citrobacter}

Strains of Citrobacter showed one major esterase band that hydrolysed $\alpha$-naphthyl esters and appeared to be slightly more active towards $\beta$-naphthyl esters than that of $L$. amalonatica (Fig. 4a). This band was inactivated by heat and inhibited by $5 \times 10^{-6} \mathrm{M}-$ DFP (see Fig. 5). One minor fast migrating band (F), $M_{F} \approx 95$, was detected by $\beta$-naphthyl acetate. Considerable variations were observed among the 14 strains in the electrophoretic mobility of the major band (Fig. $4 b$ ). In some strains an esterase band that hydrolysed $\alpha$-naphthyl acetate migrated faster than the major band. In addition, some faint bands were detected by $\alpha$ - or $\beta$-naphthyl acetates.

The molecular sieving effect in polyacrylamide disc electrophoresis indicated that the molecular size of the major esterase band of strain 40 was smaller than that of the major band of L. amalonatica strain 27 (Fig. 2). 


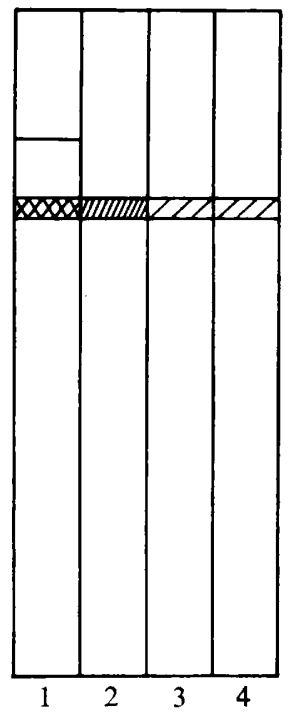

(a)

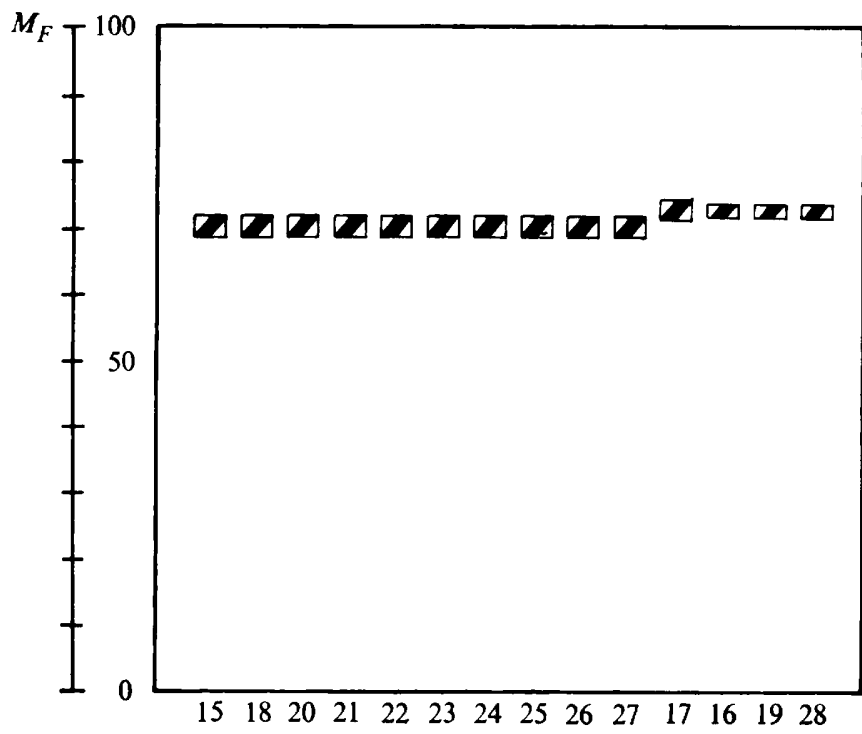

(b)

Fig. 3. Levinea amalonatica. (a) Schematic representation of mobility and activity of esterase bands (strain 27). Experimental conditions, key and relative intensity of staining as in Fig. I legend. (b) Electrophoretic distribution of the major band, $[Z]$, among the 14 strains.

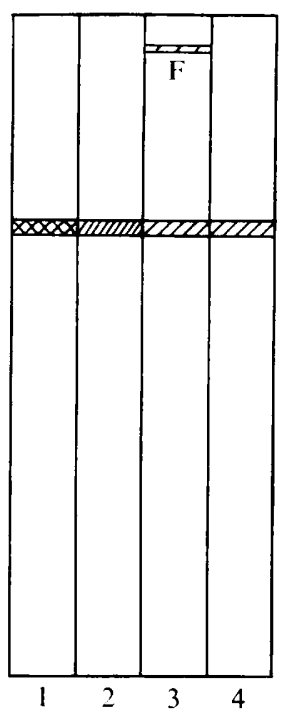

(a)

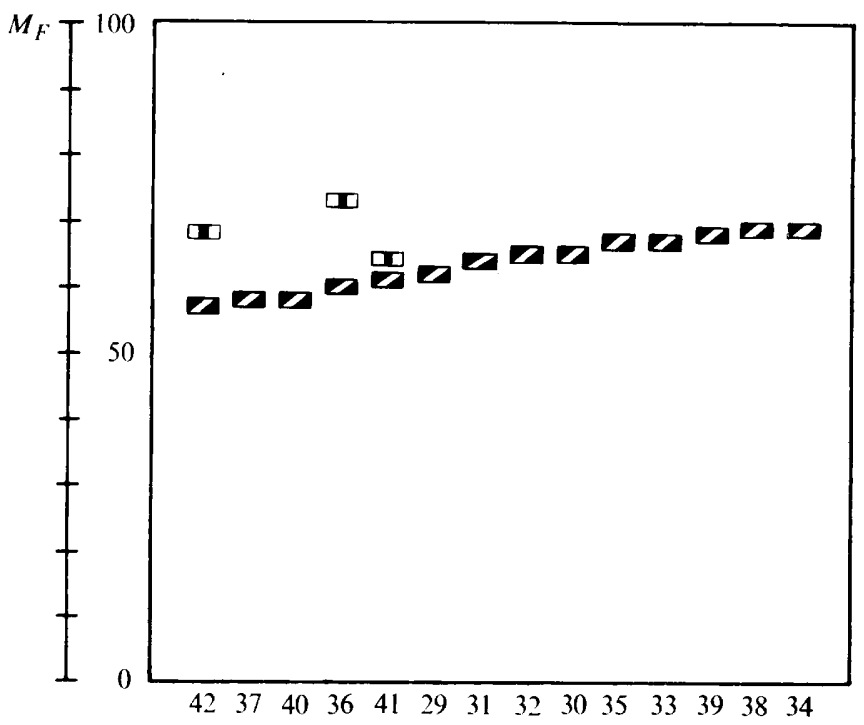

(b)

Fig. 4. Citrobacter. (a) Schematic representation of mobility and activity of esterase bands (strain 39). Experimental conditions, key and relative intensity of staining as in Fig. I legend. (b) Electrophoretic distribution of the major band, $\boldsymbol{C}$. The 14 strains are arranged in order of increasing mobility of this band. [D, Esterase band hydrolysing $\alpha$-naphthyl acetate. 


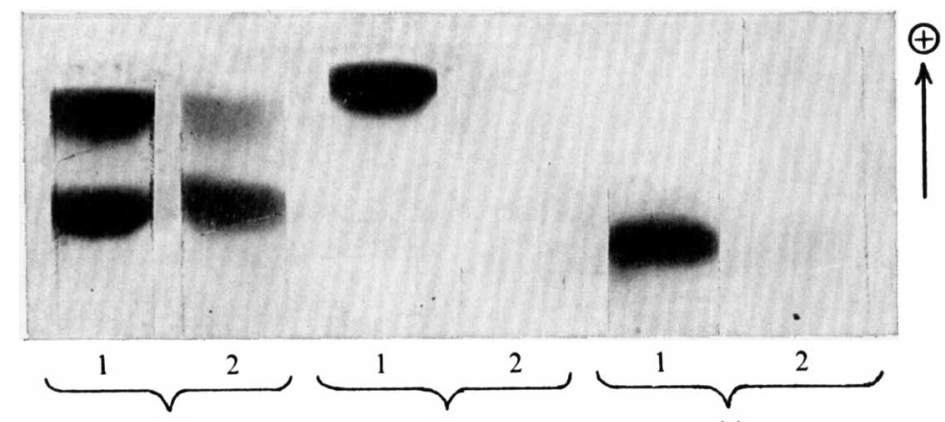

(a)

(b)

(c)

Fig. 5. DFP inhibition of the major esterase bands. Enzyme activity demonstrated with $\alpha$-naphthyl acetate as substrate. I, Untreated preparation; 2, with $10^{-6} \mathrm{M}-\mathrm{DFP}$. (a) Levinea malonatica (strain II); (b) L. amalonatica (strain 27); (c) Citrobacter sp. (strain 40).

Table 2. Characteristics of major bands of L. malonatica, L. amalonatica

Organism and esterase band

L. malonatica $\mathrm{E}_{1}$

L. malonatica $\mathrm{E}_{2}$

L. amalonatica

Citrobacter and Citrobacter

\begin{tabular}{cccc}
\multicolumn{3}{c}{ and Citrobacter } \\
Substrates* hydrolysed $\dagger$ \\
++++ & - & +++ & - \\
++++ & + & + & - \\
++++ & +++ & + & + \\
++++ & +++ & ++ & ++
\end{tabular}

Molecular sieving effect $(\operatorname{Iotg} \alpha)$ concn
of DFP (M) Electrophoretic
mobility $\left(M_{F}\right.$ value $) \ddagger$ $7 \cdot 3$ $66 \cdot 90 \pm 2 \cdot 98$ $62 \cdot 42 \pm 1 \cdot 08$ $70 \cdot 57 \pm 0.93$ $63 \cdot 42 \pm 4 \cdot 12$

$7 \cdot 3$
$6 \cdot I$
$7 \cdot 4$
$6 \cdot 0$

* $\alpha$ NA, $\alpha$-naphthyl acetate; $\alpha \mathrm{NB}, \alpha$-naphthyl butyrate; $\beta \mathrm{NA}, \beta$-naphthyl acetate; $\beta \mathrm{NB}, \beta$-naphthyl butyrate.

,,,+++++++++++ , Intensities of esterase band; - , no activity.

$\ddagger$ Mean values \pm S.D.

\section{DISCUSSION}

Extracts of strains of Levinea and Citrobacter have different esterases. The individual characteristics of the four major bands are summarized in Table 2. According to the values of the negative slope from plots of $100 \log M_{F}$ against acrylamide concentration, the molecular sizes of the $\mathrm{E}_{1}$ esterase band of $L$. malonatica and the only esterase band of $L$. amalonatica were similar. The same is true for the smaller $\mathrm{E}_{2}$ esterase band of L. malonatica and the major esterase band of Citrobacter. Further studies including other enterobacteria and using reference proteins are in progress. In addition to the above four esterases, one minor band migrating near the marker dye front and reacting with $\beta$-naphthyl acetate was observed in strains of $L$. malonatica and Citrobacter. The mobility of this fast band is distinct for each species and different from that of Escherichia coli (Goullet, 1973).

On the basis of the esterase data, distinctive patterns may be established for L. malonatica, $L$. amalonatica and Citrobacter. This differentiation is consistent with the genetic divergences detected by DNA hybridization (Crosa et al., 1974). The differences in the esterase patterns of $L$. malonatica and $L$. amalonatica are striking but the differences are less marked between $L$. amalonatica and Citrobacter, which seems to agree with the common biochemical characteristics of the last two species (Young et al., I97I; Richard et al., I972).

Considerable electrophoretic variations were observed with the L. malonatica $\mathrm{E}_{3}$ band and to a lesser degree with the Citrobacter major band. The major band of L. amalonatica 
is less variable. Thus, with respect to carbohydrate fermentation (see Table I) as well as esterase mobilities, L. amalonatica appears more homogeneous than Citrobacter.

Madame C. Gaillard is thanked for technical assistance. This work was supported by grants from the Université de Paris VII and from the Institut National de la Santé et de la Recherche Médicale (no. 75.I.II4.I) and by a gift from the Fondation pour la Recherche Médicale.

\section{REFERENCES}

Crosa, J. H., Steigerwalt, A. G., Fanning, G. R. \& Brenner, D. J. (1974). Polynucleotide sequence divergence in the genus Citrobacter. Journal of General Microbiology 83, 271-282.

Davis, B. J. (1964). Disc electrophoresis. II. Method and application to human serum proteins. Annals of the New York Academy of Sciences 121, 404-427.

Goullet, PH. (1973). An esterase zymogram of Escherichia coli. Journal of General Microbiology 77, 27-35.

GoULLET, PH. (1975). Esterase zymograms of Proteus and Providencia. Journal of General Microbiology 87, 97-106.

HEDRICK, J. L. \& SMITH, A. J. (1968). Size and charge isomer separation and estimation of molecular weights of proteins by disc gel electrophoresis. Archives of Biochemistry and Biophysics 126, 155-164.

LENNOX, E. S. (I955). Transduction of linked genetic characters of the host by bacteriophage PI. Virology I, $190-206$.

Richard, C., BRIsou, B. \& Lioult, J. (1972). Etude taxonomique de 'Levinea', nouveau genre de la famille des Entérobactéries. Annales de l'Institut Pasteur 122, I I 37-I I46.

URIEL, J. (196I). Caractérisation des cholinestérases et d'autres estérases carboxyliques après électrophorèse et immunoélectrophorèse en gélose (application à l'étude des estérases du sérum humain normal). Annales de l'Institut Pasteur ror, I04-I I9.

URIEL, J. (1966). Méthode d'électrophorèse dans des gels d'acrylamide-agarose. Bulletin de la Société de chimie biologique 48, 969-982.

Young, V. M., Kenton, D. M., Hobbs, B. J. \& Moody, M. R. (I97I). Levinea, a new genus of the family Enterobacteriaceae. International Journal of Systematic Bacteriology 21, 58-63. 